2. The advantages of an International Council of Nurses for the furtherance of the social and professional progress of nurses, and for the maintenance of a high standard of nursing ethics and esprit de corps.

3. The advantages of the affliation of international societies of experts with the International Council of Women for mutual intellectual expansion and organization.

\title{
IN HOSPITAL
}

BY M. E. R.

\section{LOW FEVER.}

ThFre was a "service of song" at the Methodist chapel across the way. As the noise came through my open window I could imagine the chapel interior-the air palpitating around the gas-burners, the unvarying type of face in the perspiring congregation, the cheap attempts at decoration, and the stifling smell of the place. On the hottest night of midsummer they were singing the delights of the Heavenly Jerusalem,-

\footnotetext{
"To be there, to be there,

Oh, what must it be to be therel"
}

So the words ran, as the stiff, untrained throats of the singers, failing at the higher notes of the refrain, flattened in horrible discord.

Sickness destroys one's power of resistance to external impressions, I suppose, for as I lay there, helpless to get away, the Heaven they sang of seemed insistently near.

Pain was not so bad, after all, though my head and side throbbed furiously; and there might be worse than to lie in the dark in a strange room, consumed with thirst. Who was that invalid, I wondered, who made a practice of cataloguing all the small pleasantnesses of her daily life, recalling them in the night watches? The way a bird cocks his head on one side when he looks at you, the shock of cool, fresh water in the morning, the first dip into a new magazine as you cut the leaves,- these, as I recalled them, were some of the things she cared to record. But I recalled them with difficulty, could not realize them at all, for that intruding conception of a Heaven all tinsel and noise.

It had been a fatal year for typhoids. Perhaps a lurking fear of being ridiculous had saved me, so far, from taking my condition too seriously; but fever plays queer pranks with one's brain, and, for a bad minute, the fear, not of death itself, but of going to an orthodox Heaven, held me as in a vise. 


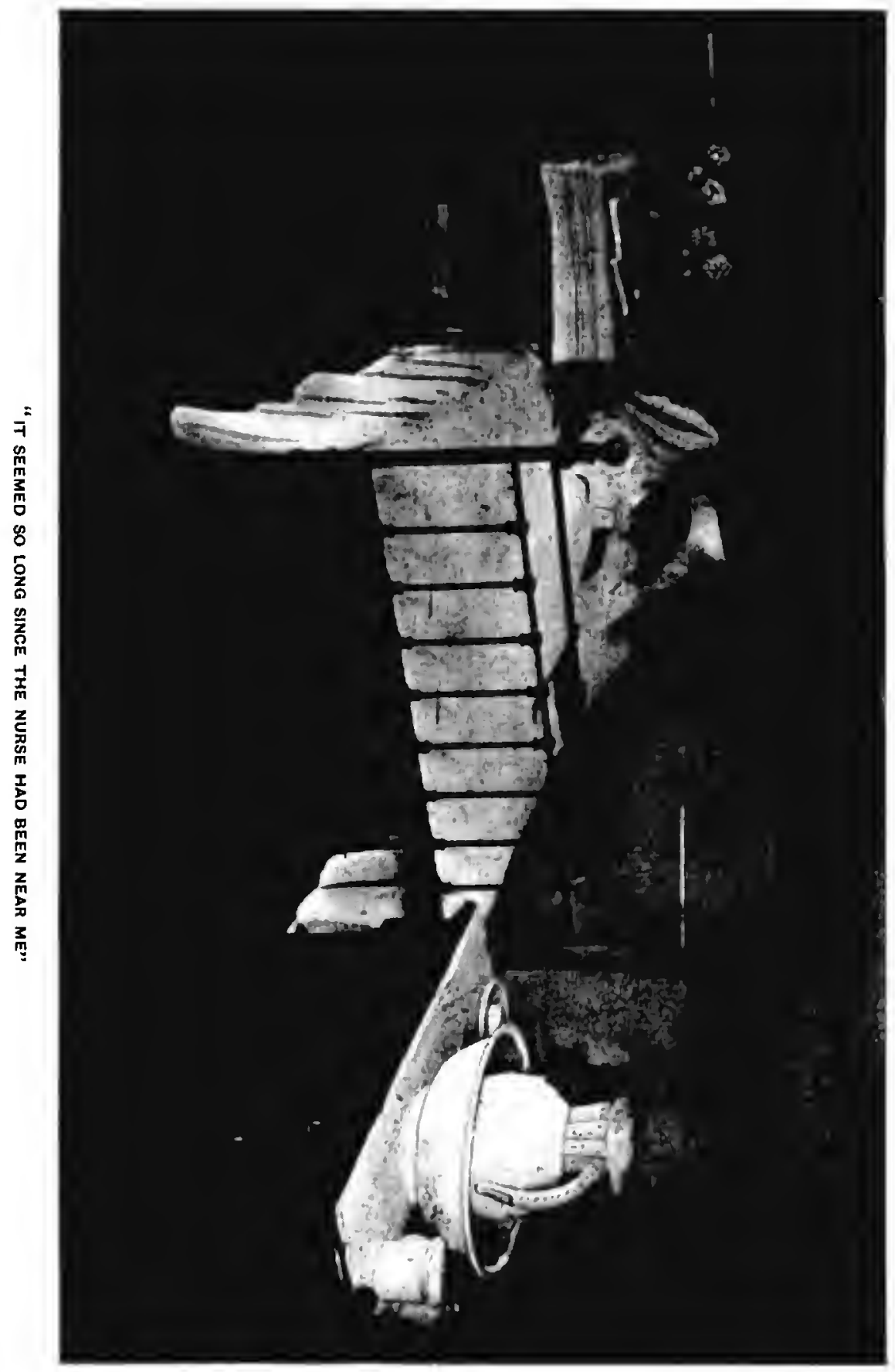


I struggled to get free. Why not make my own catalogue of pleasantnesses? That very afternoon, as the stretcher was lifted from the ambulance, had it not been a pleasant thing to look up and recognize the particular beauty of the sky which follows a cloudless summer day.? The high-hanging clouds were becoming visible, but delicately so; they were just beginning to make ready for the splendors of a late sunset. It was only a brief glimpse-in a moment the bearers were carrying me along the hospital corridors; but really to see the sky one must look it squarely in the face, and the best way to do that is to lie flat upon one's back. Then, by contrast with the throaty noises of that congregation across the way, what a pleasant thing had always been the moment of suspense when Arthur Nikisch stood above his men with baton raised, and every trained muscle, every disciplined will, was alert to give with purity the first full, satisfying tone in the strings. A moment later, when the first beat had been given, the first stroke made, how the nerves vibrated in sympathy along one's spine and to one's finger-tips! There was another pleasure, and a still better one,dusk and hear A- touch the piano; to know just what she was thinking,- but that thought had too many associations, and sent me drifting helplessly.

The woman next door could not sleep. She kept up a moaning, broken by whispered complaints to her attendant. The ward was wakeful, apparently; for, though the chapel people had turned out the lights and gone home long ago, and the clock had struck ten and then half-past with what seemed a long night between, every few minutes a bell would ring, summoning the nurse, and far off a man howled continually in uncontrollable agony. Somehow I did not mind his noise as much as I did my neighbor's - he could not help it, poor fellow.

Moonlight streamed into the corridor and slanted through my open door across a section of the floor. The outside world was breathlessly still, but a contagious unrest seemed to pervade the hospital. I listened intently for each sound, waited to be shaken by it, then turned and tossed and listened again.

It seemed so long since the nurse had been near me to arrange my pillow or bring me a drink, and the unspent hours of the night stretched endlessly far before. Even those church people might have made an agreeable diversion now. But that was the nurse's light tread along the hall, and I heard the cool tinkle of ice in a glass. Had she passed my door, I should have weakly cried, I think; but no, she came in, the tinkling growing clearer and clearer. Talk of symphony orchestras! The pleasantest music in the world is made by a lump of ice in a glass. 
II. DOOTOR'S ROUNDS.

WHEN one is lying in such unaccustomed helplessness, a hint of helplessness outside means panic. The almost military discipline of the hospital is, therefore, the patient's best prop. In so far as the extreme heat relaxes this discipline,-some of the force usually being away, house-cleaning in progress, and quiet more difficult to maintain,- -just so far is the patient's recovery retarded. My room was at the end of the downstairs or women's ward, and convalescents and their friends gathered on the veranda outside to compare notes about all the diseases they had ever known. Under this strain my temperature was mounting steadily, when the doctor had me moved upstairs to a quieter room in the men's wing. When their pain was unbearable the men howled, but they talked very little. My satisfaction in the change seemed to afford the doctor some amusement, but then, though I hardly was conscious of it at the time, he afforded me amusement too.

The doctor, his assistant, and the head nurse go the rounds together just after breakfast. There is a certain order of procedure which is, I believe, invariable. The doctor raps, enters, shakes hands with the patient, sits down; the nurse stands at the foot of the bed, instructionbook and pencil in hand; and the assistant, carrying an ink-bottle and the record of your case, stands by the mantel, ready to write down new symptoms.

On the first morning the doctor entered as if he were coming into a drawing-room, and paused with an alert air, ready to take the smallest hint. I got the impression of an athletic figure and capable head-still young and smooth-faced, but with a not very satisfactory mouth. Capable of subtlety, he yet was about to make the initial mistake of an indulgent manner. Was I thirsty? Well, I might have all the water I wanted; the nurse would please put that down. And did I care for aerated waters? Well (with an air of conceding much), there was no objection to the indulgence; the nurse might put that down also. At which $I$ did not laugh in his face, because laughing was too great an exertion.

I was in a half-stupor during the week that followed. A direct question seemed worse than a blow, and the man who called "Hucklebays!" a block away, and the other man who ground a piano-organ beyond the hospital enclosure, were no longer merely the sources of street noise. They marched across my line of life and back again, making queer, crooked turns in my dim consciousness; they advanced and retreated in waves of colored sound; between them it was to be settled whether I should live or die. 
III. HIGH FEVER.

WHY did you say-that night so long ago ?We speed so fast, though, I could never hear; Our steeds drag headlong through the molten air; The white track blinds me, and the whole world throbs With pain-a senseless, brute, ignoble pain. . . . Are you still there? Do not come near, nor look, But just in pity tell me why you ever saidFaster, faster, lash the horses on! The wind blows hotter and the throbbing grows, But Hell itself can no new horrors hold To match these surging, upturned heads. They sink, They rise, they crowd upon us here-a sea Of tragic faces, loathsome, terrible. And your face too! Time was when just your look Made heaven. Ah, when was that? Ages ago, I think. You died since then and never saidWhy did you ever say-in pity tellNay, but I will know, grappling you and Death.

I would not break your arm, dear nurse. Yes, Your hand is cooling; hold it there awhile.

IV. DETAOHMENT.

Wrine a fever at last burns low, and the patient has had no solid food for weeks, there comes a period of clear-headedness, of keen sensation, during which, if one were only stronger,-tantalizing thought,one certainly must be far cleverer than common. When this period came for me, I lay long hours of the summer days quietly thinking. The mood was one of detachment. I had no desire to establish relations with the people who moved in and out my sick-room, for old memories were my company-old memories of books, places, and people. These I read anew with quickened insight, new standards of measure. Some such experience everyone has had, I suppose, in the moment between sleeping and waking, when a vexing question will seem luminously clear, only to be obscured again by the shock of contact with reality. Happily, no such disillusioning test was to be applied to my invalid thoughts. I believed in them then and I believe in them now, though of what they were about I have no very clear recollection.

A period of such beatific self-content could not last long. It was succeeded by a craving for books, or not so much for books as for one particular form of literary thought and expression. All reading was still denied me, so there was ample time to think out the details of this form. It must be prose, but imaginative and finely done; not fiction either, for . fiction would be too much like fact. Some prose study was what I wanted, 
and I tried to think of all the essayists in turn. The eighteenth-century men were too artificial. Macaulay's sledge-hammer periods were out of the question, Lamb's whimsicalness spoilt him for the time, Arnold was too controversial, Emerson too thin-blooded, and De Quincey, who might have done very well, escaped my mind.

When it was grudgingly conceded that $\mathrm{A}-$ might read to me an hour a day, she came with a bundle of new magazines. They seemed so inadequate to the occasion that my face betrayed me. I tried to explain what I had in my mind, and, though I was incoherent enough to have puzzled anyone else, the right book was promptly at hand the next day. With the first sentences I knew that here was what I wanted. A high, weather-stained wall in a sculptor's yard, the cool close of summer at Valenciennes as the eighteenth century begins, and then the growth of Watteau's art traced step by step in the journal of a girl of the Provinces, his cousin. He had, she says, in her effort to catch the distinguishing characteristic of his style, his "cleanly preferences." What an admirable trait! so far removed from the brutality of false emphasis, of high fever. It seemed the secret-through all that delightful book, as $A-$ read it to me on three successive afternoons-of Pater's own style. But one progresses rapidly from this stage. Before "Imaginary Portraits" was finished I had begun to watch the people about me, and my first step back into the world of men and women had been taken.

\section{v. CONVALESOENCE.}

ONE of the nurses was a rich Philadelphia widow in her second year of training. The world and its allurements had palled upon her, and she proposed to dedicate herself to the slums. She could not have been more than thirty-one of your warm-cheeked brunettes and good to look upon,- - or she would have been good-looking had she never moved or spoken; her Delsartian gestures and the self-conscious modulations of her voice filled one with distrust of the bloom.

Sentimentality had marked her for its own. I knew it by the lifted eyebrows and the frown of pain between them as she counted my pulse and adjusted my pillow. I knew it by the guarded yet confidential tone in which she referred to "Marcella." Five of her friends had sent her copies of the book, and were foolish enough to think her like the heroine.

No wonder the world failed to satisfy her! But the slums must fail too. I pictured the cowed awe with which so much manner must at first oppress them, and, later on, the savage force of their revolt.

Passively to have received the ministrations of such a nurse for long, the humor of the situation must have worn off-it must have become intolerable; but, happily, I escaped this. My own nurse was somewhat 
angular,-she stooped, in fact,- - but there was a merry twinkle in her eyes, especially when they lighted on the widow, which gave assurance that one might trust her to take hold of life by the right handle. She laughed at me and my returning appetite, and fostered my interest in the hospital life by graphic little sketches of her associates and of the other patients. By the time I was promoted to a wheel-chair I knew something about each one of these.

There was the poor fellow from Canada to whom she had carried a cluster of my bunch-berries as a reminder of home. He had been very ill with the fever and a sister had come to nurse him. When he was well enough to be read to, the sister went into town to get some attractive literature, and brought back Stead's "If Christ Should Come to Chicago." Then there was the old German organist who had never missed a service for fifty years, and, waking one morning to find one side paralyzed, had received this stroke of fortune with the petulant surprise of a small child. I had known his playing-a dry, scholastic style, and had seen a text-book of his on counterpoint and thorough-bass. It appeared that the old gentleman was also a student of the Swedenborgian metaphysics, but these studies had failed to prepare him for the turn of events which suddenly had flung him on his back-it seemed to him altogether unreasonable, unprecedented. He was a troublesome patient, always ringing his bell and demanding the impossible, but I noticed that the nurses liked him. They seemed to feel that his unworldliness had received a shock, that one who had spent his life with the abstractions of musical mathematics and of the seven spheres needed time to readjust himself to the hard facts of life. I also noticed that not one of them had any patience with a little Hebrew at the end of the ward, who had been a mere bunch of acquisitiveness, probably, until rheumatism gripped him. No doubt he had suffered, but his inordinate demands were in no sense an effort to adjust his sufferings to a philosophy of things; they seemed just the old, life-long habit of asking for all he could get.

My nurse said that there were not so many "characters" in a pay ward, and that nursing in a free ward was for that reason more interesting work. There was an Irishman in the free surgical ward, she told me, for whom was prescribed two ounces of sherry daily after dinner. There was little hope that he could get well, but the sherry was always occasion for a toast, and he would propose his nurse's health in such a speech as only an Irishman can make.

I never saw him, but the patient for whom I had the friendliest feeling was a German in the free surgical. Death for him was only a question of a few weeks. He had no relatives or friends, but a fellowcountryman had agreed to pay his funeral expenses. This was not only 
a satisfaction to him-it was a source of the greatest pride. Whenever he had a bad turn he would always see to it that a letter was dispatched to prepare his benefactor for the worst. In the year and more of his sickness he had become an excellent judge of nursing, and his rebuke to the nurse who omitted the smallest item of his toilet was dignified but scathing.

Whatever had brought him to this pass (and he was silent on the subject), inefficiency certainly was not the cause. He selected the capable people on the hospital staff with an unfailing instinct, and their sympathy went out to him in return. Hopeless as his state was, he wasted not one moment in vain regrets, but, gathering his remaining strength, faced death with no smallest decency of life neglected. Absolutely clean and well-brushed he must be to the end, and then-a respectable burial.

I thought of him on my last night in the ward. Evidently my time to die had not come, as I was to be dismissed, cured, on the morrow; but when it did I should be glad to bear myself as well, should envy him his quiet and unfailing courage.

\section{THE FEEDING OF INFANTS}

By JOHN IOVETT MORSE, A.M., M.D.

Instructor in Diseases of Children, Harvard Medical School ; Aseistant Vigiting Physician at the City Hospital and at the Infants' Hospital, Boston.

Everyone must admit that the natural food for a baby during the first year is human breast-milk, and that this should preferably be its own mother's milk. Unfortunately, however, the modern woman, probably as the result of civilization and unnatural surroundings, is often unable to nurse her offspring. In such cases, of course, some substitute must be provided. Every woman, however, who can, even if only partially, nurse her infant should do so, as there is no question that babies thrive better on breast-milk than on any substitute food. The mother who can but does not nurse her baby voluntarily handicaps it in its struggle for life.

\section{BREAST FEEDING.}

It is not enough, however, merely to nurse a baby; it must be nursed in the proper way. The baby must be trained to nurse at regular intervals, and only at those intervals. The proper training of a baby, and especially the regulation of its hours of feeding, almost makes the difference between its being a blessing or a curse to the family. The 